\title{
Truss Morphometric and Meristic Characters of Male and Female Donkey Croaker (Pennahia anea (Bloch 1793)) Taken from Asemdoyong Auction Center Pemalang, Central Java
}

\author{
Adenia Arih Utarini, Suhestri Suryaningsih, Agus Nuryanto* \\ Department of Zoology, Biologi Faculty, Jenderal Soedirman University \\ *email:agus.nuryanto@unsoed.ac.id
}

Article Info

Keyword:

Donkey croaker

Sexuality

Meristic

Morphometric

Article history:

Received: 06/06/2021

Revised: 15/07/2021

Accepted: 18/07/2021

\begin{abstract}
Pennahia anea is among of the demersal fish landed at Asemdoyong Fish Auction Centre, Pemalang. P. anea doesn't show sexual dimorphism, so that other characters are needed to differentiate male and female individuals, i.e. truss morphometric and meristic characters. Previous studies have shown that truss morphometric and meristic can differentiate between male and female individuals. This study aims to describe the morphometric and meristic truss characters and determine the truss morphometrically and meristic characters that distinguish between males and females of Pennahia anea. The research used a survey method with a purposive random sampling technique. Male and female individuals of $P$. anea were examined based on their meristic and truss morphometric characters. The data were analyzed statistically using Mann Whitney non-parametric test. The result proved that male and female were significantly different in seven out of the 31 truss distances. Male individuals had a larger size than female individuals in three truss distances. In contrast, the male had a smaller size than the female individuals in four out of seven truss distances that distinguish both sexualities. The soft fin radius of the ventral fin was significantly different between male and female of $P$. anea. It could be concluded that male and female individuals of Pennahia anea have different truss distances and meristic characters with seven truss distances and one meristic character are different.
\end{abstract}

Copyright $@ 2021$ Author(s). All Right Reserved

\section{Introduction}

Indonesia is a maritime country with the second-longest coastline $(108,000 \mathrm{~km})$ (Peristiwady, 2019). Pemalang coastline is part of the Indonesia coastline that resides in the North of Central Java with approximately 35 km (Marcos, 2016; Waridin, 2007). This regency has five Fish Auction Centers (TPI), and the largest is TPI Asemdoyong (Karningsih et al., 2014; Rahmawati et al., 2013). Many fish species have been landed in Asemdoyongs' Fish Auction Center, one of which is Pennahia anea. Pennahia anea has a common name Donkey Croaker (Ernawati \& Sumiono, 2010; WoRMS, 2021).

Donkey Croaker is distributed in tropical and subtropical regions and abundant in the Indian Ocean (Wagiyo et al., 2020). The 
maximum body size found in China, Thailand, the Philippines, Malaysia, and Indonesia was $300 \mathrm{~mm}$ (Ernawati, 2007). However, P. anea that live in the Indian and Pacific Oceans has a maximum body size of $400 \mathrm{~mm}$ (Tuuli et al., 2011). P. anea belongs to the demersal fish group (Baransano \& Mangimbulude, 2011). This species lives in coastal waters with a depth of up to 60 meters and commonly found in muddy water (Wagiyo et al., 2020). P. anea has a high economic value. Its meat is consumed as a protein source, and the swim bladder is sold at a high price because of its good health benefits (Tuuli et al., 2011; Yulianto et al., 2016).

The morphological characters of $P$. anea are pointed snout, large mouth, and no barbells. It has two pairs of a tiny pore. The first pair of pores are in front of the chin, separated by symphysis. The upper teeth are larger than the lower teeth, do not have canine, the abdomen has a white colour, the caudal fin is truncate, and has 22-25 soft dorsal fins (White et al., 2013) P.anea is fish species that do not show sexual dimorphisms. In such case, male and female fish cannot be easily differentiated morphologically without specific technique. The only technique can be distinguished male and female individual is by observing their gonads through dissection (Rahardjo et al., 2011). However, that technique is not reliable for immature individuals, where gonads are not fully developed. According to Wijayanti et al. (2017), male and female immature fish individuals can be differentiated using truss morphometric and meristic characters. Therefore, this study tried to evaluate the possibility of using truss morphometric and meristic characters to distinguish male and female of $P$. anea.

Truss morphometric observes all distances between truss points on the body, then compared with standard lengths to obtain a constant value even though the observed fish size are varies (Onsoy et al., 2011). Meristic is a method of counting characters, which is done by counting certain body parts (Putri et al., 2015). Usually, the part of the body that calculated as the number of hard and soft rays on the dorsal, caudal, anal, ventral, pectoral fin, and the number of scales on the lateral line
(Radona et al., 2017). Meristic characters can be affected by environmental factors such as water salinity, water temperature, and dissolved oxygen in the water, which affects the growth process of fish larvae, so there may be different characters when the fish are adults (Resmayeti, 1994). The previous study had proven the reliability of truss morphometric and meristic characters for distinguishing male or female fish individuals (Auliana et al., 2017). Auliana et al. (2017) found that the distance between the tip of the snout and the dorsal part of the border between head and body can distinguish male and female Tontobi fish (Nematalosa erebi). At the same time, the number of fin ray in the anal fin is also a distinguishing character (Soleh et al., 2010).

This study aimed to differentiate truss distances and meristic characters of male and female individuals of Donkey Croaker (Pennahia anea) and to determine the number of truss distances and meristic characters can distinguish male and female of Donkey Croaker (Pennahia anea).

\section{Materials and Methods \\ Sampling site and times}

We focused on Pennahia anea that landed in Asemdoyong Fish Auction Center Pemalang Central Java. According to the research focus, fish samples collected from fish seller at the auction centre (Figure 1). The samples collected in April and May 2020.

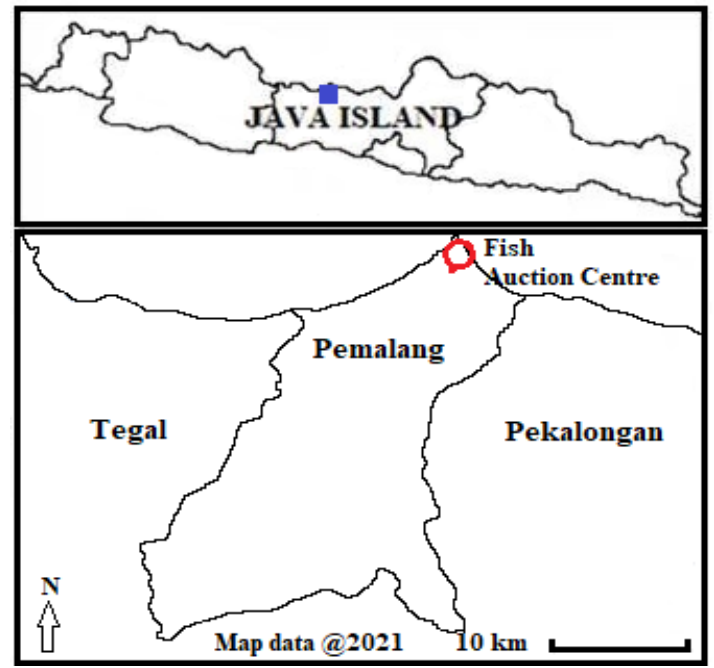

Figure 1. Sampling sites in the Asemdoyong Fish Auction Centre Pemalang, Central Java 


\section{Fish handling and identification}

A total of 30 individuals consisted of 15 individuals of male and female Pennahia anea were examined during the study. Fresh individual fish samples were placed in cooler boxes to keep their morphological performances and colour. Upon arrival in the laboratory, the specimens were put in a freezer at $-20^{\circ} \mathrm{C}$ until further examination. Trus morphometrics characters, standard and head length, were measured using a calliper with an accuracy of $0.005 \mathrm{~cm}$ (Affandi et al., 1992). Truss morphometric measurements were conducted between 16 benchmark points and 31 truss distances (Figure 2). The truss distances were summarized in Table 1 . The meristic characters were the number of gill rakers, the number of hard and soft rays on the dorsal, caudal, anal, ventral, and pectoral fins, the number of scales on the lateral line, the number of scale above the lateral line, and the number of scale under the lateral line. A total of 16 meristic characters were compared between male and female individuals (Sukmaningrum, Suryaningsih, \& Nurhaeni, 2020), with slight modification on the number of benchmark points and truss distances.

Conventional identification was performed to ensure the taxonomic status of the samples. Identification was following the identification book from (Carpenter \& Niem, 2001; Saanin, 1984; White et al., 2013). The validity of obtained scientific names was referred to the database available in FishBase (Froese \& Pauly, 2018). Phylogenetic analysis was performed through phylogenetic tree or cladogram reconstruction. The cladogram was reconstructed based on 24 morphological characters, divided into three groups of characters; the ratio between two morphometrics measure, meristic, and general morphology performance. Morphometric characters refer to Dulčić (2005). Detail characters used for phylogenetic analysis summarized in Table 1.

\section{Data analysis}

Data of truss distance and meristic characters, compared with the standard length, were analyzed using the "Mann-Whitney" test using SPSS software to distinguish male and female fish. The test was based on a $95 \%$ significance level or asymptote significance value of 0.05 . The sexuality of the fish specimens was determined through dissection. Fish was dissected from the beginning anus to the anterior part of the stomach until to behind the operculum and dissected to the ventral part using surgical scissors. Dissection was performed carefully so as not to damage the internal organs, especially the gonads. The gonad topography was observed compared to the gonad topography of fish in (Sukamto et al., 2010).

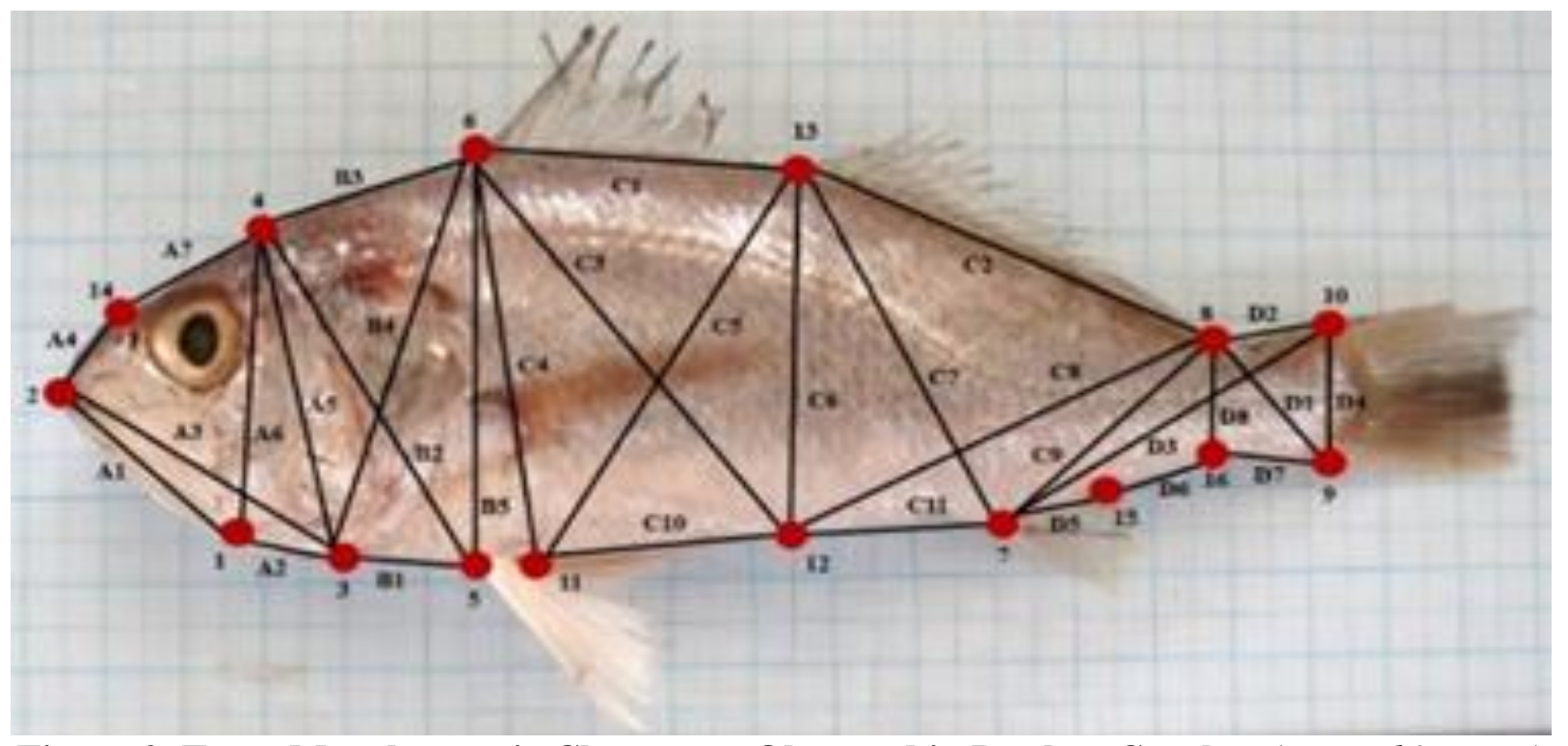

Figure 2. Truss Morphometric Characters Observed in Donkey Croaker (Pennahia anea) 


\section{Results and Discussion}

The total number of individuals fish samples used in this research was 53. The total length of fish samples ranges from 11.33 to $20.25 \mathrm{~cm}$, while the weight (Carpenter \& Niem, 2001), $P$. anea can grow up to $30 \mathrm{~cm}$ in length. According to Carpenter and Niem (2001) and White et al. (2013), Fish sample identification was conducted. It was proved that all the collected fish from TPI Asemdoyong belong to $P$. anea.
The morphological character of fish samples was fusiform with lateral line scales reaching the caudal fin's hind margin (Carpenter \& Niem, 2001). The body colour was silvery grey, with the tip of the dorsal fin blackish. The observed colour is following White et al. (2013), who stated that $P$. anea has a fusiform body shape, with silvery grey body colour. According to Carpenter and Niem (2001), $P$. anea has a grey head and body. The abdomen is paler with silvery reflection.

\section{Table 1. Morphological characters used in phylogenetic analysis of pomacentrid fish}

\begin{tabular}{|c|c|c|c|c|}
\hline Part & Body Part & No & Code & Annotation \\
\hline \multirow{7}{*}{ A } & \multirow{7}{*}{ Head } & 1 & A1 (1-2) & $\begin{array}{l}\text { The distance between the base points of the lower jaw and The } \\
\text { tip of the snout }\end{array}$ \\
\hline & & 2 & A2 (1-3) & $\begin{array}{l}\text { The distance between the base point of the lower jaw and The } \\
\text { border between head and body (ventral part) }\end{array}$ \\
\hline & & 3 & A3 $(2-3)$ & $\begin{array}{l}\text { The distance between the tip of the snout and The border } \\
\text { between head and body (ventral part) }\end{array}$ \\
\hline & & 4 & A4 (2-14) & $\begin{array}{l}\text { The distance between the tip of the snout and The prominent } \\
\text { part of the head }\end{array}$ \\
\hline & & 5 & A5 (3-4) & $\begin{array}{c}\text { The distance between the border between head and body } \\
\text { (ventral part) and The border between head and body (dorsal } \\
\text { region) }\end{array}$ \\
\hline & & 6 & A6 (4-1) & $\begin{array}{l}\text { The distance between the border between head and body (dorsal } \\
\text { part) and The base point of the lower jaw }\end{array}$ \\
\hline & & 7 & A7 (4-14) & $\begin{array}{l}\text { The distance between the border between head and body (dorsal } \\
\text { part) and The prominent part of the head }\end{array}$ \\
\hline \multirow{5}{*}{$\mathrm{B}$} & \multirow{5}{*}{$\begin{array}{l}\text { Anterior Part } \\
\text { of the Body }\end{array}$} & 8 & B1 (3-5) & $\begin{array}{l}\text { The distance between the border between head and body } \\
\text { (ventral part) and The front base of the ventral fin }\end{array}$ \\
\hline & & 9 & B2 (4-5) & $\begin{array}{l}\text { The distance between the border between head and body (dorsal } \\
\text { part) and The front base of the ventral fin }\end{array}$ \\
\hline & & 10 & B3 (4-6) & $\begin{array}{l}\text { The distance between the border between head and body (dorsal } \\
\text { part) and The front base of the } 1 \text { st dorsal fin }\end{array}$ \\
\hline & & 11 & B4 (6-3) & $\begin{array}{c}\text { The distance between the front base of the 1st dorsal fin and } \\
\text { The border between head and body (ventral part) }\end{array}$ \\
\hline & & 12 & B5 (6-5) & $\begin{array}{l}\text { The distance between the front base of the } 1 \text { st dorsal fin and } \\
\text { The front bottom of the ventral fin }\end{array}$ \\
\hline \multirow{8}{*}{$\mathrm{C}$} & \multirow{8}{*}{$\begin{array}{l}\text { Posterior Part } \\
\text { of the Body }\end{array}$} & 13 & C1 (6-13) & $\begin{array}{l}\text { The distance between the front base of the } 1 \text { st dorsal find and } \\
\text { The front bottom of the } 2 \text { nd dorsal fin }\end{array}$ \\
\hline & & 14 & C2 (13-8) & $\begin{array}{l}\text { The distance between the front base of the } 2 \text { nd dorsal fin and } \\
\text { The back base of the } 2 \text { nd dorsal fin }\end{array}$ \\
\hline & & 15 & C3 (6-12) & $\begin{array}{l}\text { The distance between the front base of the } 1 \text { st dorsal fin and } \\
\text { The midway between the ventral and anal fins }\end{array}$ \\
\hline & & 16 & C4 (6-11) & $\begin{array}{c}\text { The distance between the front base of the 1st dorsal fin and } \\
\text { The back base of the ventral fin }\end{array}$ \\
\hline & & 17 & C5 (11-13) & $\begin{array}{l}\text { The distance between the back base of the ventral fin and The } \\
\text { front bottom of the } 2 \text { nd dorsal fin }\end{array}$ \\
\hline & & 18 & C6 (12-13) & $\begin{array}{l}\text { The distance between the midway between the ventral and anal } \\
\text { fin and The front base of the } 2 \text { nd dorsal fin }\end{array}$ \\
\hline & & 19 & C7 (13-7) & $\begin{array}{c}\text { The distance between the front base of the } 2 \text { nd dorsal fin and } \\
\text { The front bottom of the anal fin }\end{array}$ \\
\hline & & 20 & C8 (8-12) & $\begin{array}{l}\text { The distance between the back base of the } 2 \text { nd dorsal fin and } \\
\text { The midway between the ventral and anal fin }\end{array}$ \\
\hline
\end{tabular}


Table 1. (Continue)

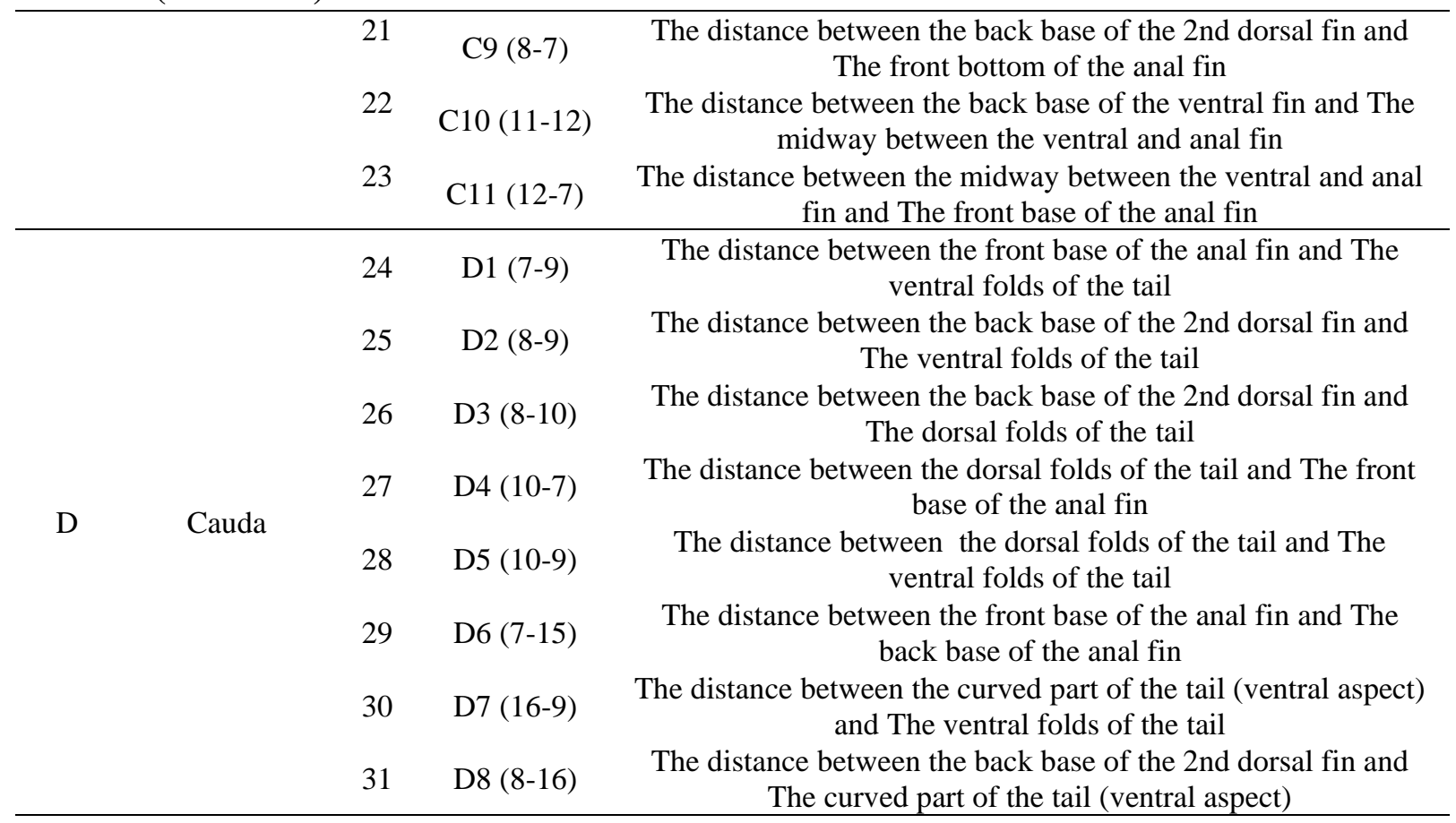

The shape of the caudal fin is truncated (Figure 4.2. (a)). The type of scale is ctenoid (Figure 4.2. (b)), but there are cycloid scales on the head (Figure 4.2. (c)). The mouth position is terminal (Figure 4.2. (d)) and has small teeth on the lower jaw and large teeth without large fangs in the upper jaw (Figure 4.2. (e)). The observed characters follow Carpenter and Niem (2001) statement that $P$. anea has cycloid scales on its head, and in other parts, it has ctenoid scales. White et al. (2013) stated that this species has large upper teeth without large canines. Other morphological characters that distinguish $P$. anea from different species don't have a barbell and have two pairs of mental pores (Puspasari et al., 2020) (Figure 4.2. (e)). According to Carpenter and Niem (2001), these two pairs of mental pores are small. Based on Sasaki (2001) and Zhu et al. (1975) Sciaenidae generally has pores at the tip of the snout and lower jaw.

Observation of gonads in $P$. anea showed that male gonad was elongated, milky white, and a pair. The female gonad was elongated, yellowish to orange, and the number was a pair (Figure 3). Both male and female gonads are located under the swim bladder. The characters follow Burhanuddin (2008) statement that the fish gonads are a pair, with the colour and size according to the level of maturity of the gonads.
The gonads are elongated, located laterally or ventrally to the swim bladder. The male gonads (testes) are whitish, while the female gonads (ovaries) are reddish-yellow.

The results of measuring the ratio between the truss distance and the standard length and tested using the "Mann Whitney" are presented in Table 2. It is summarized in Table 2 there were 7 out of 31 characters that the Asymptote Significance value less than 0.05. It was clear that the ratio of the truss distance that distinguishes male and female $P$. anea are A1, A3, B4, C8, C9, D3, and D5 (Figure 4). Based on Tuuli et al. (2011), P. anea is a gonochoric. Gonochoris is each individual has one genital (male or female). Tuuli et al. (2011) stated that the minimum size of gonad maturity for female $P$. anea was $125 \mathrm{~mm}$ in standard length, whereas, for males, it was $119 \mathrm{~mm}$.

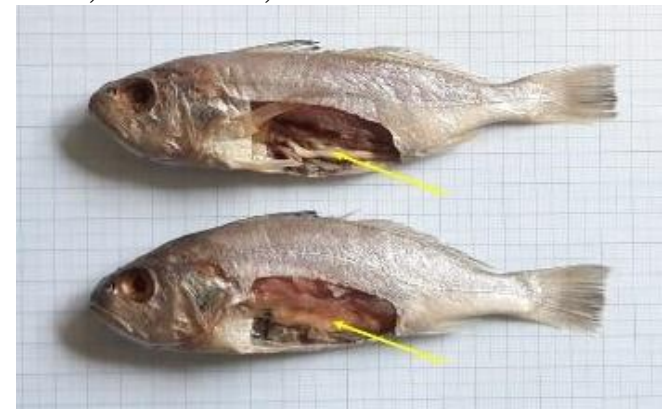

Figure 3. Gonad of Pennahia anea (a) Male Gonad; (b) Female 
Table 2. The significance value of the Mann Whitney test of truss distance between male and female individuals

\begin{tabular}{|c|c|c|c|c|c|}
\hline \multirow{2}{*}{ No } & \multirow{2}{*}{ Truss } & \multicolumn{2}{|c|}{ Mean Rank } & \multirow{2}{*}{ Asymp. Sig } & \multirow{2}{*}{ Mann Whitney Test } \\
\hline & & $\mathrm{M}$ & $\mathrm{F}$ & & \\
\hline 1 & A1 & 19.23 & 32.52 & 0.002 & $*$ \\
\hline 2 & $\mathrm{~A} 2$ & 26.95 & 27.03 & 0.986 & NS \\
\hline 3 & A3 & 21.77 & 30.71 & 0.038 & $*$ \\
\hline 4 & A4 & 30.45 & 24.55 & 0.170 & NS \\
\hline 5 & A5 & 24.41 & 28.84 & 0.304 & NS \\
\hline 6 & A6 & 26.14 & 27.61 & 0.732 & NS \\
\hline 7 & A7 & 29.36 & 25.32 & 0.348 & NS \\
\hline 8 & B1 & 27.59 & 26.58 & 0.814 & NS \\
\hline 9 & B2 & 24.82 & 28.55 & 0.386 & NS \\
\hline 10 & B3 & 22.59 & 30.13 & 0.080 & NS \\
\hline 11 & B4 & 21.91 & 30.61 & 0.043 & $*$ \\
\hline 12 & B5 & 24.73 & 28.61 & 0.367 & NS \\
\hline 13 & $\mathrm{C} 1$ & 26.50 & 27.35 & 0.843 & NS \\
\hline 14 & $\mathrm{C} 2$ & 31.68 & 23.68 & 0.063 & NS \\
\hline 15 & C3 & 25.14 & 28.32 & 0.459 & NS \\
\hline 16 & $\mathrm{C} 4$ & 24.73 & 28.61 & 0.367 & NS \\
\hline 17 & C5 & 26.00 & 27.71 & 0.691 & NS \\
\hline 18 & C6 & 25.73 & 27.90 & 0.613 & NS \\
\hline 19 & C7 & 25.18 & 28.29 & 0.470 & NS \\
\hline 20 & C8 & 32.68 & 22.97 & 0.024 & $*$ \\
\hline 21 & C9 & 33.73 & 22.23 & 0.008 & $*$ \\
\hline 22 & $\mathrm{C} 10$ & 25.50 & 28.06 & 0.551 & NS \\
\hline 23 & $\mathrm{C} 11$ & 27.64 & 26.55 & 0.800 & NS \\
\hline 24 & D1 & 26.05 & 27.68 & 0.705 & NS \\
\hline 25 & D2 & 25.23 & 28.26 & 0.481 & NS \\
\hline 26 & D3 & 32.59 & 23.03 & 0.026 & $*$ \\
\hline 27 & D4 & 26.55 & 27.32 & 0.857 & NS \\
\hline 28 & D5 & 32.68 & 22.97 & 0.024 & $*$ \\
\hline 29 & D6 & 30.09 & 24.81 & 0.220 & NS \\
\hline 30 & D7 & 26.50 & 27.35 & 0.843 & NS \\
\hline 31 & D8 & 24.91 & 28.48 & 0.406 & NS \\
\hline
\end{tabular}

The A1 character is the distance between the base points of the lower jaw and the tip of the snout. In male fish, the value was 19.23. In female fish, the value was 32.53. The A3 character is the distance between the tip of the snout and the ventral part of the border between head and body. In males, the value was 21.77 . In female fish, the value was 30.71. The B4 character is the distance between the front base of the 1st dorsal fin and the ventral part of the border between head and body. In males, the value was 21.91. In female fish, the value was 30.61. It was observed that the male individual has a shorter distance than the female individual for those three truss characters (Tjahjo \& Purnamaningtyas, 2008).

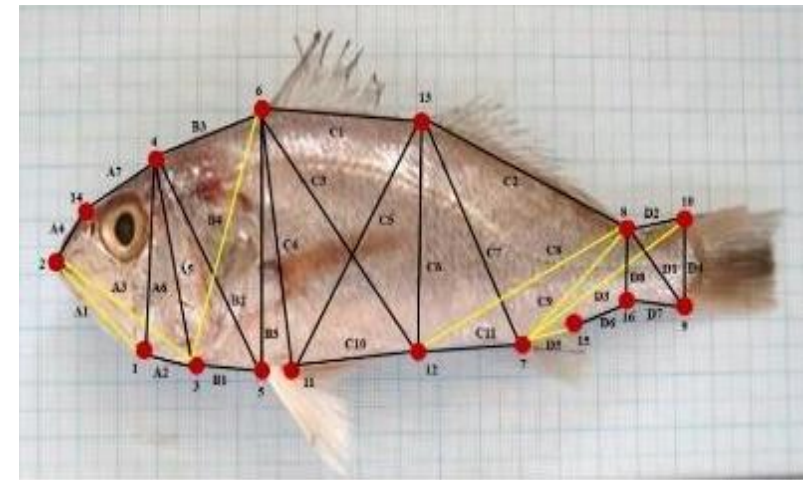

Figure 4. A significant difference in truss distance between male and female individuals.(Note: The Yellow Line was Significant, and The Black Line was NonSignificant 
In contrast, the male individual has a longer truss distance than the female individual for C8, C9, D3, and D5 truss characters. The C8 character is the distance between the back base of the 2nd dorsal fin and the midway between the ventral and anal fin. In males, the value was 32.68. In female fish, the value was 22.97. The C9 character is the distance between the back base of the 2 nd dorsal fin and the front bottom of the anal fin. In males, the value was 33.73. In the female, the value was 22.23. The D3 character is the distance between the dorsal folds of the tail and the front base of the anal fin. In the male, the value was 32.59. In the female, the value was 23.03. The D5 is the distance between the front base of the anal fin and the back base of the anal fin. In males, the value was 32.68. In the female, the value was 22.97. From the results of data analysis, it was found that female $P$. anea has a longer anterior body, while male $P$. anea has a longer posterior body.

A similar study by Asiah et al. (2019), Sukmaningrum, Suryaningsih, and Sari (2020) found that the truss morphometric characters that differentiate male and female Oxeye Scad (Selar boops) were B1, B4, B9, D2, and D5. The B1 character is the ratio of the truss distance between the dorsal part of the border between head and body and the base of the anal fin. The B4 character is the ratio of the truss distance between the dorsal part of the border between head and body and the bottom of the anal fin. The B9 character is the truss distance between the front base of the 1st dorsal fin and the front base of the anal fin. The D2 character is the ratio of the truss distance between the back base of the anal fin and the dorsal fold of the tail. It was observed that the male individual has a shorter length than the female individual for those four characters. In contrast with the D5 character, the male individual has a longer distance than the female individual. The D5 character is the ratio of the truss distance between the ventral fold of the tail and the dorsal fold of the tail.

The result of the calculation of meristic characters is presented in Table 3 From these results, it is known that $P$. anea has fin formula D1.VIII-10; D2.I.22-25; C.17-20; A.II.7-8; V.I.4-5; P.14-17. The number of scales on the lateral line was 50 to 53 . The number of scales above the lateral line was 6 to 8 . The number of scales below the lateral line was 12 to 15 . Carpenter and Niem (2001) $P$. anea has 9 to 10 hard fin rays on the 1st dorsal fin and one hard ray on the 2 nd dorsal fin with 22 to 24 soft rays. The anal fin has two hard rays and seven soft rays.

Table 3. The significance value of the Mann Whitney test of meristic character between male and female individuals

\begin{tabular}{cccccc}
\hline \multirow{2}{*}{ No } & \multirow{2}{*}{ Meristic } & \multicolumn{2}{c}{ Mean Rank } & \multirow{2}{*}{ Asymp. Sig. } & \multirow{2}{*}{ Whitney Test } \\
\cline { 3 - 4 } & & M & F & & NS \\
2 & D1H & 23.73 & 29.32 & 0.141 & NS \\
3 & D1S & 27.00 & 27.00 & 1.000 & NS \\
4 & D2H & 27.00 & 27.00 & 1.000 & NS \\
5 & D2S & 27.50 & 26.65 & 0.829 & NS \\
6 & CH & 27.00 & 27.00 & 1.000 & NS \\
7 & CS & 29.89 & 24.95 & 0.195 & NS \\
8 & AH & 27.00 & 27.00 & 1.000 & NS \\
9 & AS & 28.75 & 25.76 & 0.418 & NS \\
$\mathbf{1 0}$ & VH & 27.00 & 27.00 & 1.000 & NS \\
11 & VS & $\mathbf{2 9 . 5 0}$ & $\mathbf{2 5 . 2 3}$ & $\mathbf{0 . 0 5 0}$ & NS \\
12 & PH & 27.00 & 27.00 & 1.000 & NS \\
13 & PS & 25.07 & 28.37 & 0.415 & NS \\
14 & SoLL & 23.57 & 29.44 & 0.155 & NS \\
15 & SaLL & 27 & 27 & 1.000 & NS \\
16 & SbLL & 23.86 & 29.23 & 0.182 & 0.282 \\
\hline
\end{tabular}


Comparison to other fish species with similar body form (streamline) has been made and showed similar phenomena (Sukmaningrum, Suryaningsih, \& Nurhaeni, 2020; Sukmaningrum, Suryaningsih, \& Sari, 2020; Suryaningsih et al., 2019; Wijayanti et al., 2017). Wijayanti et al. (2017) proved that truss morphometric characters could differentiate male and female bigeye ilisha (Ilisha megaloptera). Similar result was also reported by Sukmaningrum, Suryaningsih, and Nurhaeni (2020) in Splendid threadfin (Philimanus perplexa Feltes, 1991), Sukmaningrum, Suryaningsih, and Sari (2020) in selar bengol (Selar boops); and Suryaningsih et al. (2019) in silver barb Fish (Barbonymus gonionotus Bleeker, 1849). Based on present and those previous studies, it seem that truss morphometric is a reliable technique to differentiate male and female individuals of streamline body form fish although they do not show sexual dimorphisms.

Information on male and female individuals of Pennahia anea is vital for breeding program in domestication or mariculture development of this species (Badrudin et al., 2011; Hegde et al., 2016). Information of male and female Pennahia anea is also essential for estimating population dynamic in natural populations which finally important for sustainable harvest of Pennahia anea (Lavictory et al., 2016; Suman et al., 2016).

\section{Conclusion}

Based on the result and discussion, it can be concluded that male and female individuals of Pennahia anea have different truss distances and meristic characters. Seven truss distances and one meristic character can distinguish male and female individuals of Pennahia anea. In the future studies, additional fish samples and truss distances are needed to improve the reliability of the method.

\section{Acknowledgment}

The author would like to thank all parties who have helped in the process of making this article.

\section{References}

Affandi, R., Sjafei, D. S., Rahardjo, M. F., \& Sulistiono, S. (1992). Ikhtiologi: Suatu Pedoman Kerja Laboratorium (1st ed.). Pusat Antar Universitas Ilmu Hayat IPB.

Asiah, N., Sukendi, S., Junianto, J., Yustiati, A., \& Windarti, W. (2019). Trussmorphometric and meristic characters of kelabau fish (Osteochilus melanopleurus Bleeker, 1852) from three populations in Kampar, Siak, and Rokan Rivers, Riau Province. Jurnal Iktiologi Indonesia, 19(2), 283-295. https:// doi.org/10.32491/jii.v19i2.462

Auliana, P. E., Suryaningsih, S., \& Rukayah, S. (2017). Aplikasi Identifikasi Karakter Truss Morphometrics dan Meristik pada Ikan Tontobi (Nematalosa erebi) Jantan dan Betina di Danau Rawa Biru Merauke Papua. Jurnal LPPM, 7(1), 125-140. http://jurnal.lppm.unsoed.ac.id/ojs/in dex.php/Prosiding/article/view/363

Badrudin, B., Aisyah, A., \& Ernawati, T. (2011). Kelimpahan Stok Sumber Daya Ikan Demersal di Perairan Sub Area Laut Jawa. Jurnal Penelitian Perikanan Indonesia, 17(1), 11-21. https://doi.org/10.15578/jppi.17.1.20 11.11-21

Baransano, H. K., \& Mangimbulude, J. C. (2011). Eksploitasi dan Konservasi Sumberdaya Hayati Laut dan Pesisir di Indonesia. JURNAL BIOLOGI PAPUA, 3(1), 39-45. https:// doi.org/10.31957/jbp.547

Burhanuddin, A. I. (2008). Peningkatan Pengetahuan Konsepsi Sistematika dan Pemahaman System Organ Ikan yang Berbasis SCL pada Matakuliah Ikhtiologi [Laporan Modul Pembelajaran Program Transformasi dari Teaching ke Learning Universitas Hasanuddin 2008]. Universitas Hasanuddin. 
Carpenter, K. E., \& Niem, V. H. (2001). FAO Species Identification Guide for Fishery Purposes: The Living Marine Resources of the Western Central Pacific: Vol. 5 Bony fishes part 3 (Menidae to Pomacentridae). FAO. http://www.fao.org/3/y0770e/y0770e $00 . \mathrm{htm}$

Dulčić, J. (2005). Biometric properties of damselfish, Chromis chromis (Osteichthyes: Pomacentridae) from the middle Adriatic. Acta Adriatica: International Journal of Marine Sciences, $\quad 46(1), \quad 91-98$. https://hrcak.srce.hr/82

Ernawati, T. (2007). Distribusi dan Komposisi Jenis Ikan Demersal yang Tertangkap Trawl pada Musim Barat di perairan Utara Jawa Tengah [Fish distribution and composition demersal fish caught by trawl in west season in north waters of Central Java]. Jurnal Iktiologi Indonesia, 7(1), 41-45. https://doi.org/10.32491 /jii.v7i1.222

Ernawati, T., \& Sumiono, B. (2010). Hasil Tangkapan dan Laju Tangkap Jaring Arad (Mini Bottom Trawl) yang Berbasis di TPI Asemdoyong Pemalang. Jurnal Penelitian Perikanan Indonesia, 16(4), 267274. https://doi.org/10.15578/jppi. 16.4.2010.267-274

Froese, R., \& Pauly, D. (2018). Search FishBase. https://www.fishbase.se/ search.php

Hegde, M., Padate, V., \& Rivonker, C. (2016). Seasonal variations in habitat selection and catch trends of Sciaenids (Family: Sciaenidae) from the tropical waters off Goa, west coast of India. Indian Journal of GeoMarine Sciences, 45(8), 943-951. http://nopr.niscair.res.in/handle/1234 56789/35178

Karningsih, F., Rosyid, A., \& Wibowo, B. A. (2014). Analisis Teknis dan Finansial Usaha Perikanan Tangkap Cantrang dan Payang di Pelabuhan Perikanan
Pantai Asemdoyong Kabupaten Pemalang. Journal of Fisheries Resources Utilization Management and Technology, 3(3), 158-167. https://ejournal3.undip.ac.id/index.ph p/jfrumt/article/view/5512

Lavictory, B., Wibowo, B. A., \& Jayanto, B. B. (2016). Analisis Tingkat Efisiensi Tempat Pelelangan Ikan (TPI) di Kabupaten Pemalang [Analysis of Fish Auction Eficiency Level in Pemalang Regency]. Journal of Fisheries Resources Utilization Management and Technology, 5(4), 141-146.

Marcos, H. (2016). Sistem Informasi Geografis Objek Wisata Kabupaten Pemalang. Jurnal Informatika: Jurnal Pengembangan IT, 1(2), 3639. https://doi.org/10.30591/jpit. v1i2.392

Onsoy, B., Tarkan, A., Filiz, H., \& Bilge, G. (2011). Determination of the best length measurement of fish. NorthWestern Journal of Zoology, 7(1), 178-180. http://biozoojournals.ro/ nwjz/content/v7n1/nwjz.101401.Ons oy.pdf

Peristiwady, T. (2019). Nilai dan Manfaat Taksonomi dalam Perspektif Keanekaragaman Jenis Ikan Laut di Indonesia. In LIPI PRESS. LIPI Press. https://doi.org/10.14203/press.204

Puspasari, A. A., Lestari, W., \& Setyaningrum, N. (2020). Morfologi Guild Ikan di Waduk Penjalin. BioEksakta: Jurnal Ilmiah Biologi Unsoed, 2(1), 105-108. https://doi.org/10.20884/1.bioe.2020. 2.1.1773

Putri, R. A., Elvyra, R., \& Yusfiati '. (2015). Karakteristik Morfometrik dan Meristik Ikan Lais Danau (Ompok hypophthalmus Bleeker, 1846) di Sungai Tapung dan Sungai Siak. Jurnal Online Mahasiswa (JOM) Bidang Matematika Dan Ilmu Pengetahuan Alam, 2(1), 57-66. 
https://jom.unri.ac.id/index.php/JOM FMIPA/article/view/4289

Radona, D., Kusmini, I. I., \& Fariduddin, M. H. (2017). Karakterisasi Meristik dan Morfometrik Tiga Generasi Ikan Tengadak Barbonymus schwanenfeldii Asal Kalimantan Barat, Indonesia. Jurnal Riset Akuakultur, 12(1), 1-8. https://doi.org/10.15578/jra.12.1.201 7.1-8

Rahardjo, M. F., Sulistiono, S., Sjafei, D. S., \& Affandi, R. (2011). Iktiology (Bandung). Lubuk Agung.

Rahmawati, M., Fitri, A. D. P., \& Wijayanto, D. (2013). Analisis Hasil Tangkapan Per Upaya Penangkapan dan Pola Musim Penangkapan Ikan Teri (Stolephorus Spp.) di Perairan Pemalang. Journal of Fisheries Resources Utilization Management and Technology, 2(3), 213-222. https://ejournal3.undip.ac.id/index.ph $\mathrm{p} / \mathrm{jfrumt} / \mathrm{article} / \mathrm{view} / 3851$

Resmayeti. (1994). Identifikasi Ikan. Universitas Jenderal Soedirman.

Saanin, H. (1984). Taksonomi dan kunci identifikasi ikan. Binacipta.

Sasaki, K. (2001). Sciaenidae. Croakers (drums). P.3117-3174. In K.E. Carpenter and V.H. Niem (eds.) FAO species identification guide for fishery purposes. The living marine resources of the Western Central Pacific: Vol. 5. Bony fishes part 3 (Menidae to Pomacentridae). FAO. http://www.fao.org/3/y0770e/y0770e 00.htm

Soleh, M., Suhrawardhan, H., \& Lita, N. P. S. N. (2010). Fluktuasi Asimetri Pada Ikan Lele Dumbo yang Berasal dari Tiga Lokasi Budidaya di Kabupaten Bogor. Jurnal Penyuluhan Perikanan dan Kelautan, 4(1), 29-37. https:// doi.org/10.33378/jppik.v4i1.15

Sukamto, S., Kuslani, H., \& Hatmawati, H. (2010). Teknik Pendugaan Fekunditas Telur Ikan Kebogerang (Mystus sigriceps, Bagridae) di
Waduk Ir. H. Djuanda, Jawa Barat. Buletin Teknik Litkayasa Sumber Daya Dan Penangkapan, 8(2), 6164. https://doi.org/10.15578/btl.8.2. 2010.61-64

Sukmaningrum, S., Suryaningsih, S., \& Nurhaeni, A. (2020). Sexual Dimorphism Characterization of Splendid threadfin (Philimanus perplexa Feltes, 1991). IOP Conference Series: Earth and Environmental Science, 550(012034), 1-9. https://doi.org/ 10.1088/1755-1315/550/1/012034

Sukmaningrum, S., Suryaningsih, S., \& Sari, T. J. (2020). Analisis Morfologi dan Truss Morphometrics Selar Bengol (Selar boops) Familia Carangidae. Prosiding Seminar Nasional Biologi FMIPA UNM, 1(1), 80-88. https://ojs.unm.ac.id/semnasbio/articl e/view/15312

Suman, A., Irianto, H. E., Satria, F., \& Amri, K. (2016). Potensi dan Tingkat Pemanfaatan Sumber Daya Ikan di Wilayah Pengelolaan Perikanan Negara Republik Indonesia (WPP NRI) Tahun 2015 serta Opsi Pengelolaannya. Jurnal Kebijakan Perikanan Indonesia, 8(2), 97-110. https://doi.org/10.15578/jkpi.8.2.201 6.97-100

Suryaningsih, S., Sukmaningrum, S., Amurwanto, A., \& Rahmawati, A. (2019). Karakter Morfologi dan Meristik pada Spesies Ikan Beliak Mata (Opisthopterus tardoore) Familia Pristigasteridae. Prosiding Fahutan, 1(01), 45-57. https://journal.uniku.ac.id/index.php/ prosiding-fahutan/article/view/3652

Tjahjo, D. W. H., \& Purnamaningtyas, S. E. (2008). Kajian Kebiasaan Makanan, Luas Relung, dan Interaksi Antar Jenis Ikan di Waduk Cirata, Jawa Barat [Study on food habit, niche breadth, and species interaction of food in Cirata Reservoir, West Java]. Jurnal Iktiologi Indonesia, 8(2), 59- 
65. https://doi.org/10.32491/jii.v8i2. 288

Tuuli, C. D., Sadovy de Mitcheson, Y., \& Liu, M. (2011). Reproductive biology of the greyfin croaker Pennahia anea in the northern South China Sea. Ichthyological Research, 58(4), 302309. https://doi.org/10.1007/s10228011-0228-0

Wagiyo, K., Tirtadanu, \& Chodriyah, U. (2020). Biology characteristic, abundance index and fishing aspect of donkey croaker (Pennahia anea Bloch, 1793) in the Tangerang Waters. E3S Web of Conferences, 153, 1-11. https://doi.org/10.1051/ e3sconf/202015301011

Waridin, W. (2007). Beberapa Faktor yang Mempengaruhi Partisipasi Nelayan dalam Pembangunan Komunitas di TPI Asemdoyong, Kabupaten Pemalang, Jawa Tengah. Jurnal Ekonomi Pembangunan: Kajian Masalah Ekonomi Dan Pembangunan, 8(1), 85-95. https:// doi.org/10.23917/jep.v8i1.3939

White, W. T., Last, P. R., Dharmadi, D., Faizah, R., Chodrijah, U., Prisantoso, B. I., Pogonoski, J. J., Puckridge, M., \& Blaber, S. J. M. (2013). Market Fishes of Indonesia (Jenis-jenis Ikan di Indonesia). ACIAR Monograph No. 155. Australian Centre for International Agricultural Research. http://www.ifish.id/e-library/library/ recource/14.\%20Market\%20fishes\% 20of\%20Indonesia.pdf
Wijayanti, T., Suryaningsih, S., \& Sukmaningrum, S. (2017). Analisis Karakter Truss Morphometrics pada Ikan Kemprit (Ilisha megaloptera Swainson, 1839) Familia Pristigasteridae. Scripta Biologica, 4(2), 109-112. https://doi.org/10. 20884/1.sb.2017.4.2.400

WoRMS. (2021). WoRMS - World Register of Marine Species-Pennahia anea (Bloch, 1793). http://www.marinespecies.org/aphia. php? $\mathrm{p}=$ taxdetails\&id $=282195$

Yulianto, G., Suwardi, K., Adrianto, L., \& Machfud, M. (2016). Status Pengelolaan Sumberdaya Ikan Demersal Sekitar Pantai di Kabupaten Indramayu, Jawa Barat. OmniAkuatika, 12(3), 1-10. https://doi.org/10.20884/1.oa.2016.1 2.3.113

Zhu, Y., Yun-Ling, L., \& Han-ling, W. (1975). A study on the classification of the sciaenoid fishes of China, with description of new genera and species. Translation series (Virginia Institute of Marine Science); no. 27. Virginia Institute of Marine Science, William \& Mary. https:// scholarworks.wm.edu/reports/33 